\title{
HIGH SCHOOL APPLICATION OF A MATHEMATICAL SOFTWARE SUPPORTING PROBLEM-SOLVING
}

\section{Szerzők:}

Négyesi Péter (Drs.)

Eszterházi Károly Egyetem

Oláhné Téglási Ilona (PhD)

Eszterházi Károly Egyetem

Racsko Réka (PhD)

Eszterházi Károly Egyetem

Első szerző e-mail címe:

mathnek@gmail.com

\section{Lektorok:}

\author{
Mező Ferenc $(\mathrm{PhD})$ \\ Eszterházi Károly Egyetem \\ Szabóné Balogh Ágota (PhD) \\ Gál Ferenc Egyetem
}

...és további két anonim lektor

\begin{abstract}
Absztrakt
PROBLÉMAMEGOLDÁST TÁMOGATÓ MATEMATIKAI SZOFTVER KÖZÉPISKOLAI ALKALMAZÁSA
\end{abstract}

Noha a számelmélet az egyik legrégebbi és legtermészetesebb matematikai törekvés, néhány témája nem része a magyar középiskolák matematikai tananyagának. Megvizsgáltuk, hogy testreszabott webalkalmazásunk, beleértve a szorosan kapcsolódó feladatgyūjteményt és egy együttmúködési felületet, támogathatja-e a hallgatók problémamegoldási stratégiáját ezekben a feladatokban, és így támogathatja-e a középiskolai oktatásba történő bevezetésüket. Ebből a célból a Jász-Nagykun-Szolnok megyei 4 középiskolával $(\mathrm{N}=352)$ vettük fel a kapcsolatot a honlap fejlesztése, a számelméleti feladatgyűjtemény előkészítése és az együttműködési felület létrehozása után. A tanulókat véletlenszerūen egy kísérleti (EXP) és egy kontroll (CON) csoportba soroltuk, ahol az új számelméleti témák tanulmányozása során cak az EXP tagjainak és aárainak volt hozzáférése a weboldalunkhoz, de a CON csoport tagjai és tanáraik nem férhettek hozzá. Feltételeztük, hogy az EXP tagjai jobb vizsgálati eredményeket mutatnak a CON csoporthoz képest, ami jelzi a weboldalunk lehetséges előnyeit az új témák bevezetése során. A Mann-Whitney U teszt jobb összesített eredményeket tárt fel az EXP csoportban a CON-hoz képest $(\mathrm{p}<.001)$. Ezenkívül a Kruskal-Wallis tesztek azt mutatták, hogy az EXP 
csoportba tartozó tanulók mindegyik feladatban magasabb pontszámot kaptak (mindegyik p <0,05), ami a weboldal sikerét jelzi. Célunk a mintanagyság növelése és további webalkalmazások fejlesztése a övőbeni tanulmányaink során.

Kulcsszavak: együttműködés, számelmélet, feladatgyűjtemény, webalkalmazás

Diszciplinák: pedagógia, matematika, infomratika

\begin{abstract}
Although number theory is one of the oldest and most natural mathematical pursuits, some of its topics are not part of the Hungarian high schools' mathematics curriculum. We examined whether our custom-made web application, including a closely-related task collection and a collaboration interface, may support the problem-solving strategy of students in these tasks, thus supporting their introduction to high school education. For this purpose, we contacted 4 high schools from Jász-Nagykun-Szolnok county $(\mathrm{N}=352)$ after developing the website, preparing the number theory task collection, and creating the cooperation interface. Subjects were randomly assigned to an experimental (EXP) or control (CON) group, where members of EXP but not CON and their teachers had access to our website when studying the new number theory topics. We hypothesized that members of EXP will show better test results as compared to CON, indicating the potential benefits of our website during the introduction of new topics. Mann-Whitney $U$ test revealed better overall results in EXP as compared to CON ( $p<.001)$. Moreover, Kruskal-Wallis tests showed that subjects EXP vs. CON had higher points in each task (all $\mathrm{p}<.05$ ), indicating the success of our website. We aim to increase the sample size and to develop additional web applications in our future studies.
\end{abstract}

Keywords: collaboration, number theory, task collection, web application

Disciplines: pedagogy, mathematics, information technology

Négyesi Péter, Oláhné Téglási Ilona és Racsko Réka (2020): High school application of a mathematical software supporting problem-solving. Mesterséges intelligencia - interdiszciplináris folyóirat, II. évf. 2020/2. szám. 35-41. doi: 10.35406/MI.2020.2.35

\section{Introduction}

Student motivation is one of the most critical issues in the entire education system today, especially in the field of mathematics. Their attention is precisely focused only when the information is delivered through pictures or videos, however, they only able to concentrate for a short period of time. Because conventional methods appeared to be less effective in arousing their interest, there is a need to develop new strategies. Polya (1962) pointed out that solving a problem equals to finding a way out from a difficult situation, achieving a goal that we 
would otherwise have not been able to reach directly. For this purpose, collaboration between students might be a useful way that requires the provision of interfaces and tools (Lopez-Morteo, López 2007).

Previous surveys (Csányi, Fábián, Szabó, Szabó 2015) have shown that number theory education in high schools is extremely deplorable. Critical thinking is essential for learning number theory, therefore, using smartphones can be useful for mathematics education, as it also develops algorithmic thinking, logical thinking and the ability to concentrate with appropriate web tools (Fehér, Hornyák 2013). Web-based visual aids not only encourage students but also promote the development of their critical thinking (Agustina, Farida, Wicaksono 2020).

To support this idea, we developed a website, prepared a collection of number theory tasks and created a cooperation interface. In the present study we aimed to investigate whether our custom-made website may support the problem-solving strategy of high school students in number theory-related mathematical tasks. We hypothesized that our web applications and collaborative interface will support students' efficiency in solving the task collection, indicating that topics not found in most of the high schools' curriculum can be successfully introduced into the education. The primary goal of our research is to emphasize the use of ICT tools in mathematics education by optimizing our web applications for computers, smartphones, and tablets in terms of both appearance and functionality. In addition, our undisguised goals are to arouse students' interest and increase their motivation.

\section{Materials and Methods}

\section{Subjects}

9-11 ${ }^{\text {th }}$ graders $(\mathrm{N}=352)$ were randomly assigned to an experimental (EXP) or control $(\mathrm{CON})$ groups with the involvement of their mathematics teachers.

\section{Experimental procedures}

Members of EXP and their teachers had access to our website during the teaching process of the new topics, while members of CON and their teachers could not use it. The processing took place in six 45-minute lessons, and then, with the help of the worksheet-generating application in our website, the students had to solve a printed, 6task, intermediate-level worksheet on their own. Students completed the same worksheet in each school and that they could receive a maximum of 8 points for their solutions.

\section{Intermediate-level worksheet}

- Task1: A picture of each student in the graduating classes is placed in the school yearbook. They want to place the images by department separately to each line have the same number of images. How many is the maximum number of images they can put in a row, if there are 30 and 25 members in the classes? 
- Task2: Merlin, the Wizard, delighted King Arthur with the following interesting task: on Avalon Island you can only pay with silver coins equivalent to 115 and 50 cents. Can a product cost 1100 cents and how many different ways can it be paid out?

- Task3: The screen aspect ratio of traditional TVs is 4: 3 . Screen sizes are usually characterized by the length of the diagonal. How wide and how high a screen with a diagonal length of 55 $\mathrm{cm}$ ?

- Task4: What are positive integers that have exactly four positive divisors, and their sum equals with 84 ?

- Task5: Is there a square number among the perfect numbers?

- Task6: The measures of the edges of a rectangle are integers. Adding the measures of the volume of the rectangle, half its surface, and the length of the edges starting from one vertex, we get 2014. What are the edges of the rectangle?

Data acquisition, data analysis and statistical analyses

In line with the requests from the participating high schools, the examinations were carried out between 10th February 2020 $28^{\text {th }}$ February 2020, including both the evaluation of the worksheets and the statistical analysis (data cleaning, screening of outliers, statistical tests). To determine the differences between the two groups' overall results, Mann-Whitney U test was performed. For a more detailed analysis, we ran Kruskal-Wallis tests to determine whether subjects in the EXP and CON groups had different results in each task. Statistical significance was set at $\mathrm{p}$ $<0.05$. Results were interpreted by $95 \%$ confidence intervals.

\section{Analysis of Results}

As a result of the Mann-Whitney test $[\mathrm{U}=$ 10641,500 Z $=-5,085 \mathrm{p}<.001$ (2-tailed) $\mathrm{r}$ $=.27]$ and the Wilcoxon rank sum $[W=$ $26217.500 Z=-5.085 p<.001$ (2-tailed) $r$ $=.27$, it was found that, overall, the results of the EXP group participants were significantly better than those of the CON group participants. Moreover, as a result of the Kruskal-Wallis test (Figure 1)

- $\quad F 1:\left[\chi^{2}(1, N=352)=4.610 p=.032\right.$

- F2: $\left[\chi^{2}(1, N=352)=4.602 p=.032\right.$

- F3: $\left[\chi^{2}(1, N=352)=4.143 p=.042\right.$

- F4: $\left[\chi^{2}(1, N=352)=4.116 p=.042\right.$

- F5: $\left[\chi^{2}(1, N=352)=3.988 p=.046\right.$

- $\quad F 6:\left[\chi^{2}(1, N=352)=4.803 p=.028\right.$

We came to the conclusion that the efficiency of our method is significantly shown that subjects EXP vs. CON had higher points in each task (all $\mathrm{p}<.05$ ), indicating the success of our website. 
Figure 1. The difference per task between the CON (1) and EXP (2) group
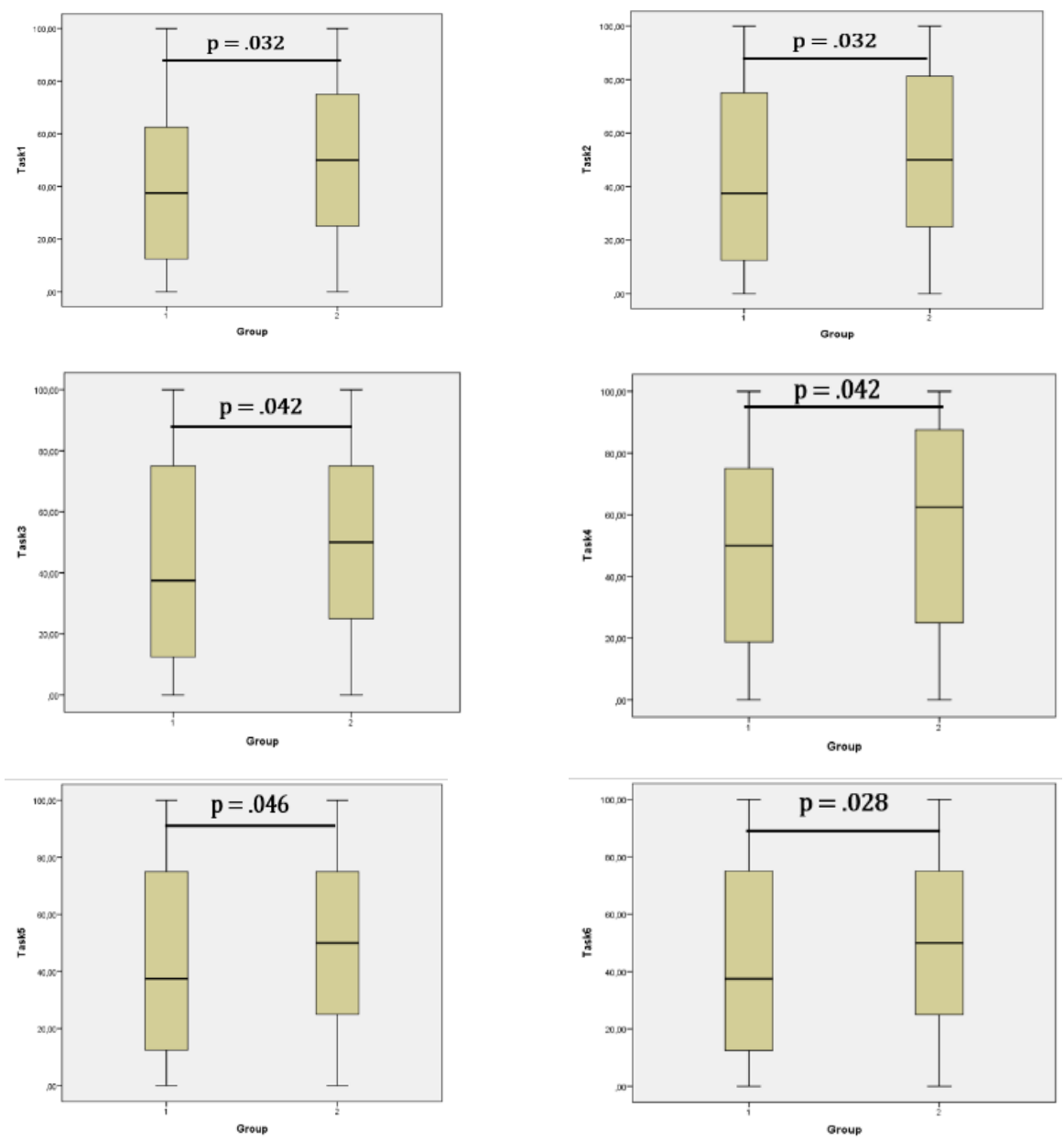

\section{Conclusions}

As shown in Figure 2, in line with our that our web applications can be efficiently hypothesis, participants in EXP had better overall result as compared to $\mathrm{CON}$, indicating used to successfully introduce new topics to mathematics education in high schools. 
Figure 2. The overall difference between the CON (1) and EXP (2) group.

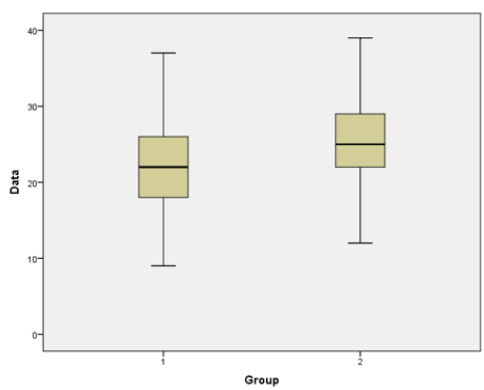

\section{Future Plans}

We aim to increase the sample size by extending our study to $12^{\text {th }}$ grades students. Moreover, our motivation is to develop additional web applications in our future studies. In addition, we also plan to compare data from intermediate and advanced number theory tasks to detect if the level of the task may affect the efficient application of our mathematical software. Finally, we also aim to develop an automatic monitoring/evaluation system.

\section{References}

Agustina, R., Farida, N. and Wicaksono, S. (2020). Experimentation of ProblemBased Learning Model on Critical Thinking Ability in Learning Number Theory. Journal of Physics: Conference Series. Volume 1467. Issue 35.

Csányi, P., Fábián, K., Szabó, Cs. and Szabó, Zs. (2015). Number theory vs. Hungarian highschool textbooks: The fundamental theorem of arithmetic. Teaching Mathematics and Computer Science. Volume 13. Issue 2. pp 209-223.

Fehér, P. and Hornyák, J. (2011). 8 hours of rest, 8 hours of fun, or Netgeneration 2010 research experiences. ELTE Eötvös Publisher. Budapest. pp 101-109.

Lopez-Morteo, G. and López, G. (2007). Computer support for learning mathematics: A learning environment based on recreational learning objects. Computers \& Education. Volume 48. Issue 4. pp 618-641.

Polya, G. (1962). Mathematical Discovery on Understanding, Learning, and Teaching Problem-solving. Volume I-II. Wiley.

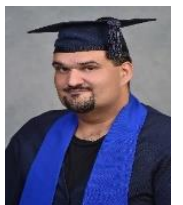

Péter Négyesi received the B.Sc. degree in Mathematics from Eszterházy Károly University in 2017 and the M.Ed. degree in Teaching of Informatics and Teaching of Mathematics from Eszterházy Károly University in 2020. Currently, he is a $\mathrm{PhD}$ student and has been working as a primary school teacher majoring in mathematics and computer science for 5 years; his research fields are developing mathematical web applications and e-learning environments which support adaptability and problem-solving.

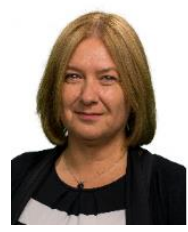

Ilona Oláhné Téglási PhD has been involved with studies related to the methodology of teaching 
mathematics. Her research fields are questions of developing primary and secondary school students' mathematical competences, and strategies of experiential teaching of mathematics. After working as a secondary school teacher of mathematics for 20 years, she's teaching mathematics didactical courses at the Faculty of Mathematics in the Eszterházy Károly University as an associate professor.

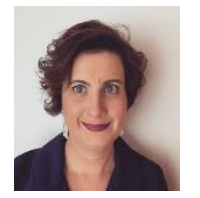

Réka Racsko PhD is working at the Institute of Digital Technology of the Eszterházy Károly College as a college senior lecturer and as a head of Department of Human Informatics. For the past 10 year she has been working in higher education and she spent a year in ICT private sector ( $\mathrm{T}$ System). As part of her role as ICT assistant and assistant lecturer she organizes and esearches many ICT-innovations and pilot projects of electronic learning enviroment (Classmate PC, e-book, tablets, LEGO tools) in K12 age group and teach special subject for $\mathrm{Ba}$ and MA level teacher. She finished her PHD studies in 2017. 